\title{
Consumers' Attitudes Towards Online Shopping: A Comparative Study of Male and Female Consumers
}

\author{
Tanjil Hossain* Halima Afrin Razia Sultana Rokaiya Rosul Itu \\ MBA (Strategic \& International Management), Department of Management, University of Dhaka, Dhaka, \\ Bangladesh
}

\begin{abstract}
Online shopping is very popular in today's modern world. Because of Covid-19, people are frequently using online shopping. This study tries to find out the male and female consumer's attitudes towards online shopping. It is of descriptive nature and mostly based on the primary data sources. Purposive sampling technique is used and 200 samples have been collected from different participants. After analysing it is found that apparel and footwear, food, accessories, electronics are the main products consumers purchase from online and time saving, easy to place order, searching the product easily, large selection of products encourages to shop online while low quality, fraud, inability to touch the product work as barrier to online shopping.
\end{abstract}

Keywords: Online Shopping, Product Preferences, Encouraging Factors, Barriers, Consumers

DOI: $10.7176 / \mathrm{JMCR} / 75-04$

Publication date: January $31^{\text {st }} 2021$

\section{Introduction}

Online shopping is a kind of electronic commerce that permits consumers to directly purchase products and services from a vendor over the internet using websites, social media etc. It is a process where consumers purchase goods or services from a seller without any intermediary. Nowadays online shopping is becoming more attractive for numerous reasons. In the present situation of Covid-19, people are getting more attached to online shopping. Many people try to avoid crowded market as they feel uncomfortable. As people lead a busy life they want to save their valuable time by purchasing online. Purchasers can easily visit various websites to see catalogs of different products and can shop by clicking just on their electronic gadgets. The interesting thing about online shopping is during holidays it alleviates the need for waiting in a long queue in the market going from store to store for searching a particular item.

In today's era, multichannel has taken place and online shopping is flourished globally because of diversified trade and commerce. Globally, e-commerce is composed of a \$2.29 trillion market (John, 2018) and targeted to reach $\$ 4$ trillion by 2020 (eMarketer, 2016) because of double-digit worldwide increase in sales $(15 \%)$ and order (13\%) (eMarketer, 2018) in all types of e-commerce. In 2016, the contribution of the Asia Pacific region of online sales is $\$ 1$ trillion and most of it came from China which was about \$899 billion (eMarketer, 2016). Islam (2019) reported, Bangladesh's e-commerce market has a net worth of $\$ 1.6$ billion currently and is targeted to be doubled to $\$ 3$ billion by 2023 .

There exist many factors that influence consumers purchasing behavior online, one of them is gender (Rahman et al., 2018). Men and woman base their purchase decision on different rational, motives, perspectives and considerations. There are many observable differences in how men and women behave as buyers. Wahyuddin et al. (2017) stated that generally, men try to find out the reason why they should buy a specific product or service and that's why men put more importance on the logic-based approach. On the other hand, emotive shopping experience is needed for making women purchasing a product. Women are interested to know more about brands, lifestyles, products etc. Women visit more websites and compare different options more thoroughly than men. Women make decisions based on emotion. On the contrary, men make decisions based on facts and data. Normally, women consider both subjective and objective information, while men rely on objective information.

\section{Critical Literature Review}

When people purchase products or services directly from the vendor through electronic media, it is called online shopping. Many people are using websites, Facebook and different apps to purchase a large selection of products and services, from daily commodities to transport tickets. Consumer product preference varies from person to person. When people select an online platform, they have plentiful options to pick their products and services.

Arora \& Aggarwal (2018) stated in their paper that convenience, price and variety of products are the important factors considered by Indian women. Because of convenience and time saving, consumers are doing online shopping in Pakistan (Bashir, 2013). Kumar \& Singh (2014) shows that hedonic and utilitarian are the main motives of women for shopping. When women do shop for enjoyment and fun that is hedonic shopping. Utilitarian shopping is a problem solver approach and is done when a need or problem arises. Rahman et al. (2018) and Alba et al. (1997) said that in Bangladesh, for getting numerous benefits such as reduced cost of transportation, wide variety of choices, saving time, home delivery, ease in shopping and variety of products, online shopping would 
become more popular to the consumers. Rahman et al. (2018), Chen \& Barnes (2007) also found that inability to touch the product is one of the barriers to online shopping. Gommans et al. (2000) trust plays an important role in consumers' online buying behavior and one of the major reasons for consumers' not using e-commerce frequently is fear of online fraud (credit card fraud, non-delivery of product).

Rahman et al. (2018), Lakshmi (2016) and Bashir (2013) stated that the young generation such as students and professionals are fond of online shopping. Li \& Zhang (2002) found that female online shoppers prefer using catalogs to shop at home while men online shoppers are more adopting in online shopping. He also stated that once female consumers find online shopping interesting, they will shop more regularly online than their male counterparts. Rastogi (2010) found in India, the percentage of male consumers in online shopping is 73 and it is very high. Rodgers \& Harris (2003) found that men were more emotionally satisfied with Internet shopping than women.

Hoque et al. (2015) said generally trust and perceived benefit are the determinants of consumer attitudes toward online shopping. Sharma (2015) concluded that risk aversion and innovativeness are two main factors that influence the consumers for decision making in online shopping. How much consumers need to be certain and sure of what they are purchasing are the measures of risk aversion. When consumers are highly risk averse, they need to be very confident about what they are purchasing and when consumers are less risk averse, they can tolerate some risk and uncertainty in their purchases. The second is innovativeness which is an international measure that captures the degree to which consumers are willing to take chances an experiment with new ways of doing things. Menon \& Kahn (2002) said consumers have a more positive attitude toward online shopping and are more likely to adopt the internet as a shopping medium if they enjoy their online shopping experience. Women have a relatively less positive attitude towards online shopping (Wu, 2003).

Bashir (2013) showed that the reasons behind the demand for electronic goods are convenience, time saving and the best price. Omar \& Hirst (2006) said generally women show positive attitude towards online shopping for apparels. Nirmala \& Dewi (2011) found men online shoppers have higher intentions to shop for fashion products online as compared to their female counterparts. Stafford et al. (2004) also stated this gender gap in online shopping. Pastore (2000) said a survey conducted reveals that men prefer to buy electronics while women shop for clothing, beauty products, health and toys.

In Bangladesh, Rahman et al. (2018) and Alba et al. (1997) found some factors that attract consumers toward online shopping. Rahman et al. (2018) also stated online shopping is getting acceptance in the young generation. It is found that there is no such study in Bangladesh that compares male and female consumer's product preferences and factors influencing on their purchasing decision and the barriers to online shopping. That is why this topic is taken to fulfill the below mentioned objectives.

\section{Objectives of the Study}

- To explore the preferred products that consumers purchase from online

- To identify the encouraging factors that influence on online shopping

- To identify the barriers to online shopping

- To show the comparison between male and female consumers on online shopping

\section{Methodology}

This research is descriptive in nature. The philosophy of this research is interpretivism and inductive approach is followed here. Both qualitative and quantitative data are used in this research. This study is based on the primary and secondary data sources. Primary data have been collected through questionnaire and secondary data have been collected from different articles. There exist a lot of people using online marketplace. It is difficult to identify the whole population involving in online shopping and that's why purposive sampling is chosen from non-probability sampling technique. 200 samples have been collected for conducting this research. The following hypothesis is developed. Based on the previous study of (Santhi \& Gopal, 2018) the hypothesis of this study is tested by chi square. The significance level is assumed at $5 \%$.

HO A: There is no association between gender and product preferences on online shopping

$H 1 A$ : There is association between gender and product preferences on online shopping

$H O B$ : There is no association between gender and factors influencing on online shopping

$H 1 \mathrm{~B}$ : There is association between gender and factors influencing on online shopping

$H O C$ : There is no association between gender and barriers to online shopping

$H 1 C$ : There is association between gender and barriers to online shopping

\section{Analysis and Findings}

In this chapter, the differences in consumer's product preferences and factors that encourage on purchasing from online between male and female consumers are explored. Charts have been used to visualize the differences perfectly and the interpretation is given beneath the charts. The first part is shown demographic analysis and 
findings and the rest part is main analysis and findings.

\subsection{Demographic Analysis}

Figure 5.1.1: Gender

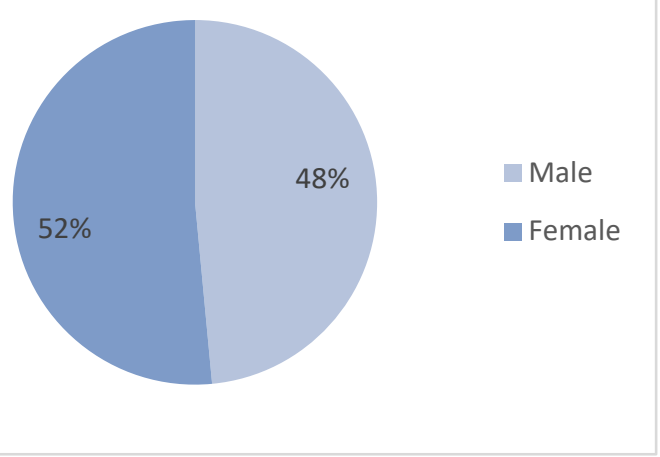

This chart shows that the proportion of male and female respondents of this research. Questionnaire method has been used for collecting data and it has been collected from 200 respondents. The respondents can be divided into two categories and these are male and female. From 200 respondents, 97 responses are from male and 103 responses are from female which is $48 \%$ and $52 \%$ of the total respondents.

Figure 5.1.2: Age groups of male and female
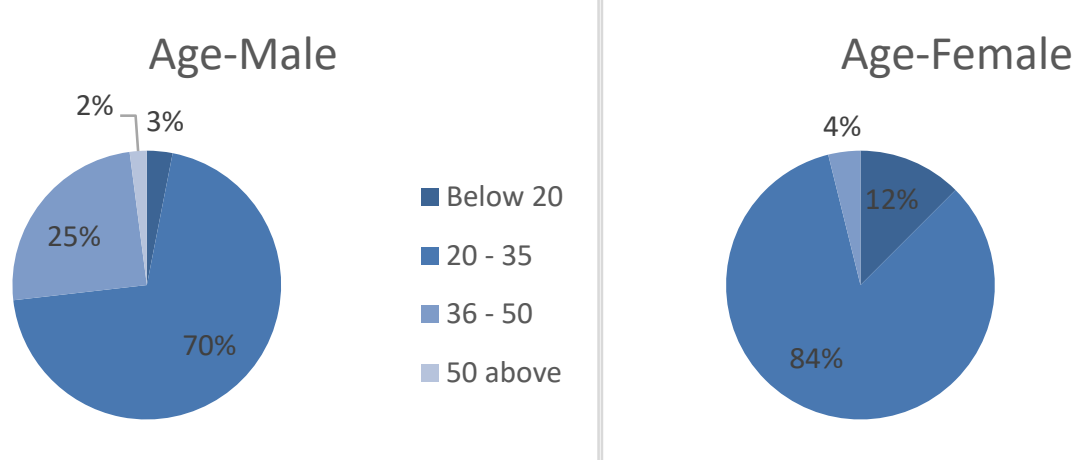

- Below 20

口 20 - 35

- $36-50$

In this chart, it can be seen that the 200 respondents are divided in 4 age groups and these are below $20,20-35$, $36-50$ and 50 above.

Male: There are 3 respondents in below 20 group resulting in only $3 \%$ of total male respondents. There are 68 respondents in 20-35 age group resulting in $70 \%$ of total male respondents. 24 respondents have been found in 3650 age group which makes a percentage of 25 of total male respondents. There are only 2 male respondents under above 50 age group resulting in $2 \%$ of total male respondents

Female: There were 13 respondents in below 20 group resulting in $12 \%$ of total female respondents. There were 87 respondents in $20-35$ age group resulting in $84 \%$ of total female respondents. 3 respondents have been found in 36-50 age group which makes a percentage of 4 only. There were no respondents in above 50 this age group. From the responses of the female respondents, it is found that female belonging to age group of $20-35$ does mostly online shopping and after that female having age below 20. As the age group increases further, their participation severely declines on online shopping. A completely different scenario is seen in the response of male online shoppers. The participation is least above 50 age group and highest in age group $20-35$ and the second highest is in age group $36-50$. So, the participation of male on online shopping gradually declines as their age increases and their participation on online shopping is the most in age between $20-50$. 
Figure 5.1.3: Occupations of male and female

Occupation-Male

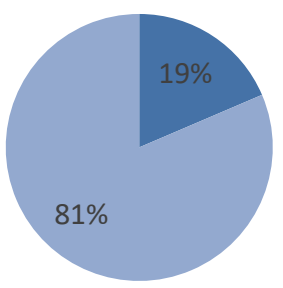

\section{Occupation-Female}

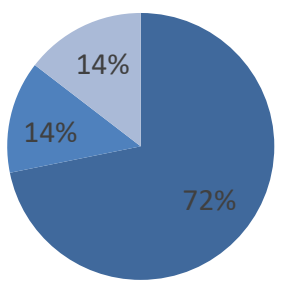

Student

- Employed

- Housewife

These charts show the proportion of occupation between male and female respondents. From the 200 respondents of male and female, their occupation is divided into three categories and these are student, employed and housewife. Student and employed are the occupations of male and student, employed and housewife are the occupations of female.

Male: From 97 responses of male, 18 responses are students and 79 responses are employed which is $19 \%$ and $81 \%$ of total male responses.

Female: From 103 responses of female, 74 responses are students, 14 responses are employed and 15 responses are housewives which are $72 \%, 14 \%$ and $14 \%$ of total female responses.

A big difference is noticed that a major portion of employed male respondents and student female respondents are online shoppers. The portion of male students using online shopping in compared to female students is very low where the portion of female employed respondents using online shopping in compared to male employed is tiny.

\subsection{Analysis of the Objectives:}

In this part of the analysis, chi square test is used based on the previous study of (Santhi \& Gopal, 2018) and the descriptive difference is used based on the previous study of (Rahman et al., 2018).

Chi Square Test: The above-mentioned hypothesis is tested by the following chi square. The observed table of chi square is given in appendix.

Table 5.2.1: Test of Hypothesis

\begin{tabular}{|c|c|c|c|c|c|}
\hline $\begin{array}{c}\text { Null } \\
\text { Hypothesis (HO) }\end{array}$ & $\begin{array}{c}\text { Alternative } \\
\text { Hypothesis (H1) }\end{array}$ & $\begin{array}{c}\text { Table } \\
\text { Value }\end{array}$ & $\mathbf{X}^{\mathbf{2}}$ & $\begin{array}{c}\text { Comparison of Table Value } \\
\text { and } \mathbf{X}^{\mathbf{2}}\end{array}$ & Comment \\
\hline H0 A & H1 A & 19.675 & 91.47 & $19.675<91.47$ & H0 A, Rejected \\
\hline H0 B & H1 B & 16.91 & 14.21 & $16.91>14.21$ & H0 B, Accepted \\
\hline H0 C & H1 C & 11.07 & 11.26 & $11.07<11.26$ & H0 C, Rejected \\
\hline
\end{tabular}

- $\mathrm{H} 1 \mathrm{~A}$ is accepted that means there is association between gender and product preferences on online shopping.

- $\quad \mathrm{H} 1 \mathrm{~B}$ is rejected that means there is no association between gender and factors influencing on online shopping.

- $\quad \mathrm{H} 1 \mathrm{C}$ is accepted that means there is association between gender and barriers to online shopping 


\section{A. Product preferences of consumers:}

Figure 5.2.1: Product preferences of consumers

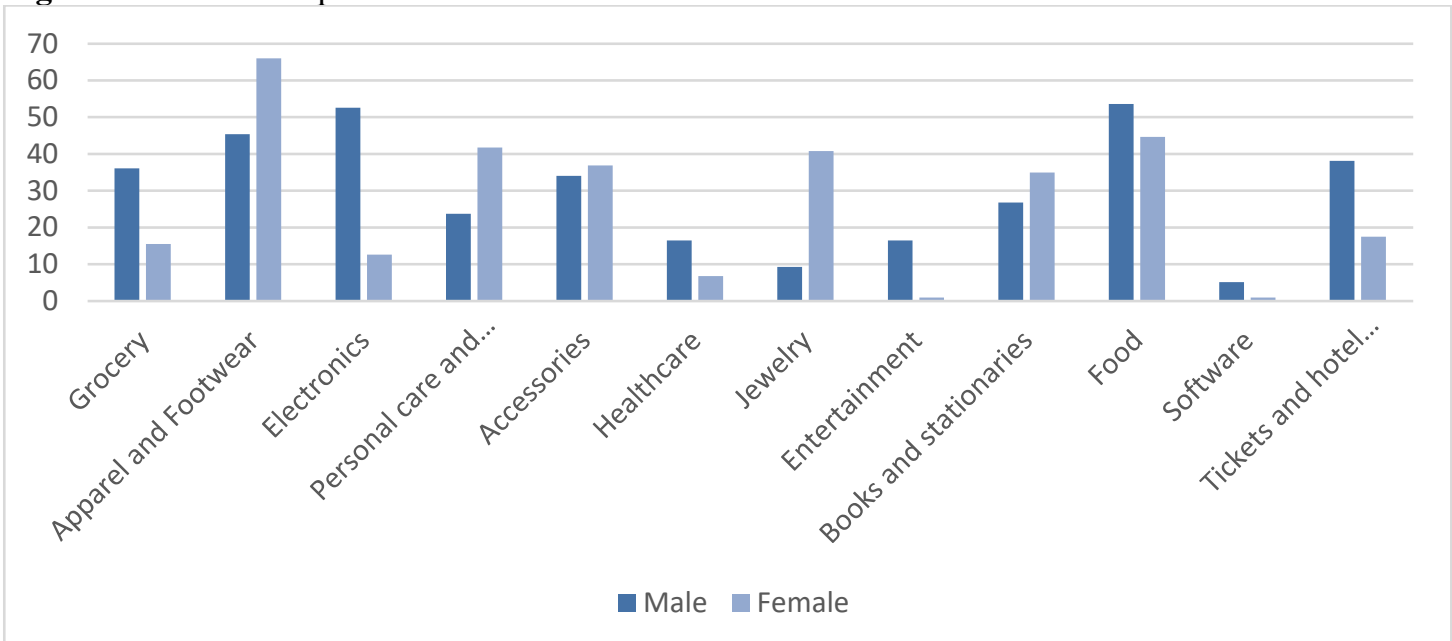

This chart shows the preferred products of consumers and also the differences in product preferences between male and female online shoppers.

From the respondents, it is found that the major products most consumers buy from online are Apparel and Footwear, Food, Accessories, Personal Care and cosmetics, electronics, Tickets and hotel booking, Books and Stationaries, Jewelry. A huge gender-based difference is seen in the purchase of electronics as $52 \%$ of male online shoppers and only $12 \%$ female online shoppers purchase electronics. There is almost $40 \%$ difference between them. Also, $41 \%$ of female online shoppers and only $9 \%$ male online shoppers purchase jewelry. There is almost $31 \%$ difference between them. It can be said that females are more prone to buy jewelry from online than male. Here, $66 \%$ female online shoppers and only $45 \%$ male online shoppers purchase apparel and footwear from online. From chart, it can be seen that more than $20 \%$ male purchase tickets and hotel booking service from online than female. Overall, it can be concluded that most male online shoppers prefer to purchase electronics, grocery, entertainment, and tickets and hotel booking services where most female shoppers prefer to purchase apparel and footwear, jewelry and personal care and cosmetics products from online. From the chart, it can also be said that male shoppers are less likely to buy personal use products from online than female.

\section{B. Factors influencing on online shopping of consumers:}

Figure 5.2.2: Factors encouraging on online shopping of consumers

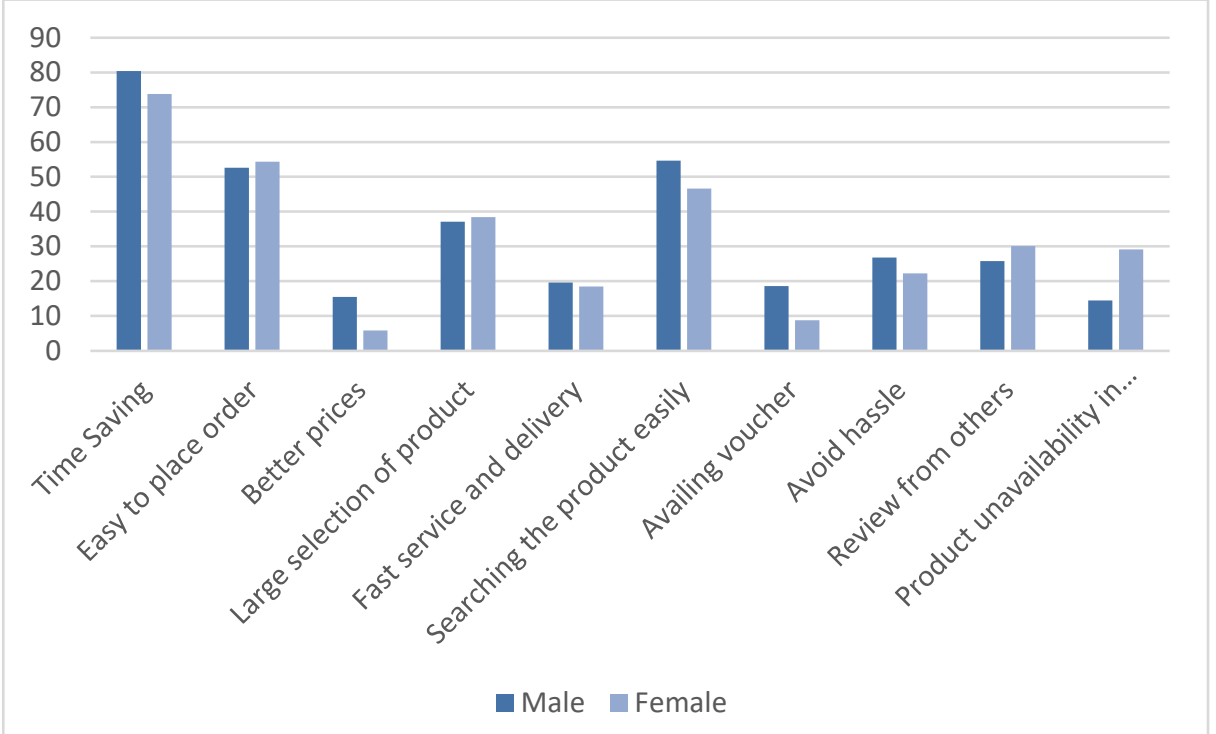

This chart illustrates the encouraging factors for choosing online shopping and also shows the comparison of male and female consumers.

From the chart, it can be said time saving, easy to place order, searching the product easily, large selection of product, review from others are the main factors influencing consumers to shop online. Also, it can be seen that female shoppers go for online shopping mostly because of unavailability of the product in the local market and almost $15 \%$ more females participate in online shopping than male for this reason. It is also found that female 
online shoppers are least bothered about the price to shop online. Whereas male online shoppers participate in online shopping mostly for getting better prices and to avail vouchers. Almost $10 \%$ male shoppers participate in online shopping than female online shoppers for both given reasons. It is found that Female online shoppers give more importance to review as almost 5\% more females participate in online shopping because of positive review from peers or known persons. Male online shoppers on the other hand give more importance on time as it is found that almost $7 \%$ more male participate on online shopping to save time, $8 \%$ more to get the product easily. Male shoppers are also bothered by the hassle of buying physically so $4 \%$ more male shoppers than female go for online shopping.

C. Barriers to online shopping of consumers:

Figure 5.2.3: Barriers to online shopping of consumers

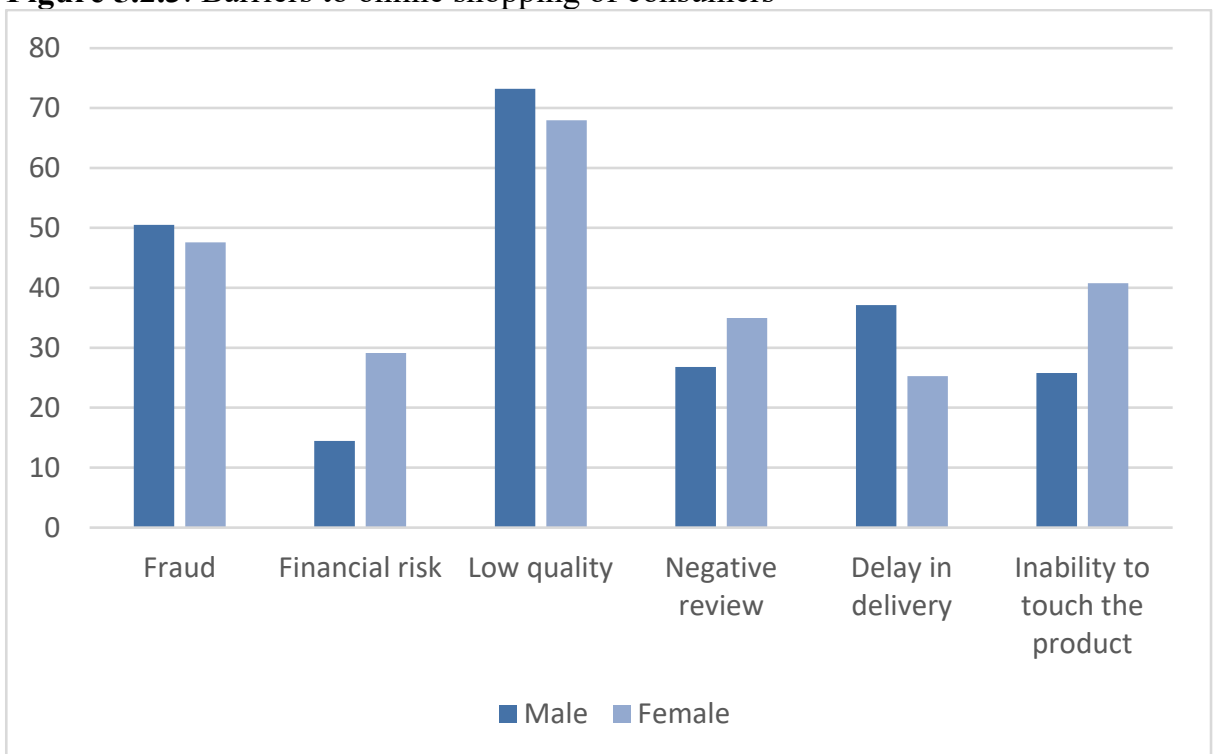

The findings are shown in the chart and it can be understood that low quality, fraud, inability to touch the product are the main barriers of online shopping. Male shoppers mainly refrain from online shopping because of delay in delivery and almost $12 \%$ more males than females refuse to shop online for this reason. This finding was obvious as in this study, it was found previously that time saving is the most dominating reason of going for online shopping for males. Inability to touch the product is the main reason behind females not going for shopping online and as a result, $15 \%$ more females than males not go for shopping online. It is found that males are more concerned with quality while shopping in online and more than $5 \%$ males than females do not choose to shop online for this reason. For females, another dominating reason that discourages online shopping is financial risk and almost $15 \%$ more females than males are concerned with this reason. So, it can be said that, while online shopping even if females are less interested in getting low or better prices, they are highly aware of the money they are spending. Female shoppers also put high importance on review so negative review is another dominating reason which discourages $8 \%$ more female shoppers than men to shop online.

\section{Discussion:}

Based on the analysis and findings a model has been developed to show the comparative view of consumers attitudes towards online shopping.

In product preferences view, male online shoppers prefer to purchase household products such as grocery and consumer electronics. As time saving is one of the encouraging factors, male online shoppers do not want to spend time in a long queue to buy transportation tickets rather they prefer to purchase it online. On the contrary, female online shoppers prefer to purchase personal wear and care products. It indicates that female is concerned about personal beautification.

In encouraging factors view, male online shoppers are generally encouraged by better price and time saving. It indicates that male is concerned about money and time. On the other hand, female online shoppers are encouraged by other's review and unavailable products in local market. It indicates that female depends on other's judgment and prefer exclusive products which are unavailable in the local market. 


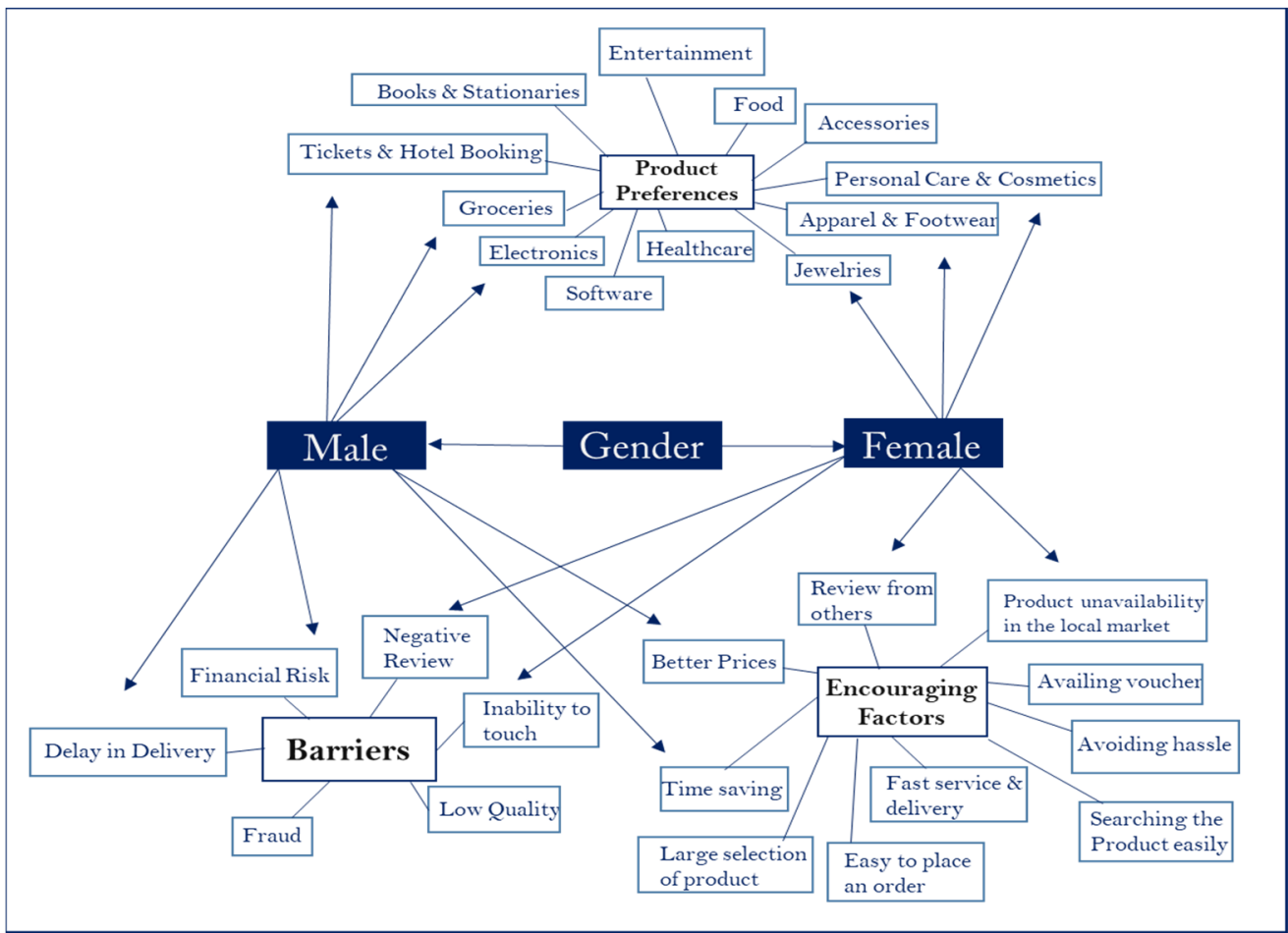

Source: Authors

In barriers view, the main barriers to male online shoppers are financial risk and delay in delivery. As it was previously found that male online shoppers are more concerned about time and money, any possibility of financial risk and delay in delivery discourage them to shop online. On the other hand, the main barriers to female online shoppers are negative reviews and the inability to touch the products. As it was found that females' purchasing decision are based on others reviews so any negative review discourages using online shopping. Moreover, female prefer to see, touch, feel and test the products and that is why the inability to touch is the barrier.

\section{Conclusion:}

This study has been successful by finding all the objectives. 103 females and 97 males participated in this study and it is found that the main products consumers purchase from online are apparel and footwear, electronics, food, groceries, personal care products, jewelry, tickets and hotel booking. The main reasons behind online shopping are time saving, easily getting the product and easy placement of order whereas the main barriers to online shopping are low quality, fraud, inability to touch the product. In terms of gender-based comparison, females mainly purchase apparel and footwear whereas males prefer buying electronic products. Time saving is the main reason behind males going for online shopping where females go for online shopping because of the unavailability of the product. Financial risk discourages female shoppers shopping online while delay in delivery is that fact that demotivates male shoppers shopping online. It is also found that male shoppers don't prefer buying personal products from online while female shoppers mainly buy personal things and books from online. Healthcare products and software are the least purchased products from online. Online sellers can use these findings to set their target group or revamp their marketing strategies. Apart from time saving review plays an important role in online shopping so online sellers should put high focus on it. Financial risk, low quality and fraud are the barriers in online shopping and by removing these problems the amount of online shopping can be increased.

\section{Limitations of the Study}

The main purposes of this study are to expose the major products consumers purchase online and while doing so the main factors that encourage or discourage their online shopping. As another objective, this study tried to find the differences in online shopping based on gender and a model is also constructed on the basis of the findings. For the entire study, the sample size was 200 where participants were from different divisions of Bangladesh. Although the findings of the study help to understand the objectives properly, a bigger sample would have helped to get more variation.

\section{Avenues of Future Research}

This study shows a clear difference in product choices, encouraging factors and barriers based on gender. Moreover, this study found that the number of female online shoppers decreases as their age increase. Male online shoppers 
are reluctant to purchase personal products (Apparel, Personal Care) online. Also, Bangladeshi online shoppers including both male and female purchase less entertainment service compared to other products and services. Future research can be conducted on these findings to find out the reasons.

\section{References}

Alba, J., Lynch, J., Weitz, B., Janiszewski, C., Lutz, R., Saywer, A., \& Wood, S. (1997). Interactive Home Shopping: Consumer, Retailer, and Manufacturers Incentives to Participate in Electronic Marketplaces. Journal of Marketing. 61 (3): 38-53.

Arora, N., \& Aggarwal, A. (2018). The Role of Perceived Benefits in Formation of Online Shopping Attitude among Women Shoppers in India. South Asian Journal of Business Studies. 7 (1): 91-110.

Bashir, A. "Consumer Behavior towards Online Shopping of Electronics in Pakistan." MBA thesis. Seinäjoki University of Applied Sciences, 2013. Print.

Chen, Y., \& Barnes, S. (2007). Initial trust and online buyer behavior. Industrial Management \& Data Systems. 107 (1): 21-36.

eMarketer. (2016). Worldwide retail ecommerce sales will reach $\$ 1.915$ trillion this year. Available at https:/www.emarketer.com/Article/Worldwide-Retail-Ecommerce-Sales-Will-Reach-1915-trillion-ThisYear/1014369 [Accessed 13 Nov. 2020]

eMarketer. (2018). Retail Ecommerce Performance Metrics, Worldwide Performance Metrics, Estimates and Historical

Data.

Available

at https://www.emarketer.com/performance/channel/58fe47a2d2670009840a9ec7/58dd63dd2357af0c900b4d3 3 [Accessed 13 Nov. 2020]

Gommans, M., Krishnan, K.S., Scheffold, K.B., (2001). From brand loyalty to e-loyalty: A conceptual framework. Journal of Economic and Social Research. 3 (1): 43-58.

Hoque, M. R., Ali, M. A., \& Mahfuz, M. A. (2015). An Empirical Investigation on the adoption of e-Commerce in Bangladesh. Asia Pacific Journal of Information Systems. 25 (1): 1- 24 DOI: 10.14329/apjis.2015.25.1.001

Islam, M. Z. E-commerce sales to reach \$3b in 4 years. The Daily Star. 17 Dec. 2019

John, S. (2018). E-commerce trends + facts 2018. Available at https://endertech.com/blog/e-commerce-trendsfacts [Accessed 13 Nov. 2020]

Kumar, V., \& Singh, R. (2014). Women Online Shopping: A Critical Review of Literature. SSRN Electronic Journal. Available at DOI: 10.2139/ssrn.2466824 [Accessed 5 Sep. 2020]

Lakshmi, S (2016). Consumer Buying Behavior Towards Online Shopping, International Journal of ResearchGranthaalayah. 4 (8): 60-65.

Li, N., \& Zhang, P. (2002). Consumer Online Shopping Attitudes and Behavior: An Assessment of Research. In Eighth Americas Conference on Information Systems (pp. 508-517). Dallas, Texas. Retrieved from https://www.researchgate.net/publication/2557074_Consumer_Online_Shopping_Attitudes_and_Behavior_ An Assessment of Research

Menon, $\overline{\text { S., }}$ \& Kahn, $\bar{B} . \overline{(2002)}$. Cross-category effects of induced arousal and pleasure on the internet shopping experience. Journal of Retailing. 78(1): 31-40. DOI: 10.1016/s0022-4359(01)00064-1

Nirmala, R \& Dewi, I. J. (2011). The Effects of Shopping Orientations, Consumer Innovativeness, Purchase Experience, and Gender on Intention to Shop for Fashion Products online. Gadjah Mada International Journal of Business. 13(1): 65-83.

Omar, O., \& Hirst, A. (2006). Apparel shopping: a focus on the attitudes of women towards online shopping. International Journal of Electronic Marketing and Retailing. 1 (2): 169. DOI: 10.1504/ijemr.2006.011032

Pastore, M. (2000). Demographics Influence Online Spending. Retrieved from https://www.clickz.com/demographics-influence-online-spending/80960/ [Accessed 5 Oct. 2020]

Rahman, M. A., Islam, M. A., Esha, B. H., Sultana, N. \& Chakravorty, S. (2018). Consumer buying behavior towards online shopping: An empirical study on Dhaka city, Bangladesh, Cogent Business \& Management. Available at DOI: 10.1080/23311975.2018.1514940 [Accessed 31 Aug. 2020]

Rastogi, A. K. (2010). A Study of Indian Online Consumers \& Their Buying Behavior. International Research Journal 1 (10): 80-82

Rodgers, S., \& Harris, M. A. (2003). Gender and E-Commerce: An Exploratory Study. Journal of Advertising Research. 43(3): 322-329

Santhi, V. \& Gopal, N. (2018). The Consumer Behaviour towards Online Shopping in Coimbatore city- An Exploratory study. International Journal of Pure and Applied Mathematics. 120 (5): 1459-1489.

Sharma, C. (2015). Consumer Buying Behaviour Towards Online Shopping - A Review of Literature, Indian Journal of Applied Research. 5 (4): 854-856.

Shah, J. Online Shopping Increases. Prothom Alo. 29 Dec. 2014. Available at http://www.en.prothomalo.com/bangladesh/news/57411/Online-shopping-increases [Accessed 19 Oct. 2020] 
Stafford, T., Turan, A. \& Raisinghani, M. (2004). International and Cross-Cultural Influences on Online Shopping Behavior. Journal of Global Information Technology Management. 7 (2): 70-87.

Wahyuddin, M., Setyawan, A., \& Nugroho, S. (2017). Shopping Behavior Among Urban Women. Mediterranean Journal of Social Sciences, 8 (1), 306-311.

Wu, S. (2003). The Relationship between Consumer Characteristics and Attitude toward Online Shopping. Marketing Intelligence \& Planning. 21 (1): 37-44.

\section{Appendix}

A Questionnaire on Consumer's Attitudes towards Online Shopping: A Comparative Study of Male and Female

1. Name:

Consumers

2. Age range:

- $\quad$ Below 20

- $20-35$

- $36-50$

- 50 above

3. Gender:

- Male

- Female

4. Occupation:

- Student

- Employed

- Housewife

5. Types of products you prefer to buy from online (You can choose multiple options)

- Grocery

- Apparel \& Footwear

- Electronics

- Personal care and cosmetics

- Accessories

- Healthcare

- Jewelry

- Entertainment

- Books and Stationaries

- Food

- Software

- $\quad$ Tickets \& Hotel Booking

6. What are the factors that encourage you to use online shopping? (You can choose multiple options)

- Time Saving

- Easy to place an order

- Better Prices

- $\quad$ Large selection of products

- $\quad$ Fast service \& delivery

- Searching the product easily

- To avail Voucher

- Less complexity

- To avoid hassle

- Review from other consumers

- $\quad$ Product unavailability in domestic market

7. What are the barriers you face while shopping in online? (You can choose multiple options)

- Fraud

- Financial risk

- Low quality

- Negative review

- Delay in delivery

- Inability to touch the product 